\title{
Temporomandibular Disorder: Prevalence Among Hemophiliac Patients
}

\author{
Trastorno Temporomandibular: Prevalencia en Pacientes Hemofílicos
}

Thatiana B. Guimarães*; Mariana B. Ferreira-Cabrini**; Camila L. Quaglio**; Antonio Sergio Guimarães ${ }^{* * *}$; Ricardo Luiz Smith"; Sandra Vallin Antunes ${ }^{* * * *}$ \& Luis Garcia Alonso ${ }^{* *}$

GUIMARÃES, T. B.; FERREIRA-CABRINI, M. B.; QUAGLIO, C. L.; GUIMARÃES, A. S.; SMITH, R. L.; ANTUNES, S. V. \& ALONSO, L. G. Temporomandibular disorder: prevalence among hemophiliac patients. Int. J. Odontostomat., 9(2):295$300,2015$.

ABSTRACT: The objective was to investigate the prevalence of temporomandibular dysfunction -TMD - in severe and moderate hemophiliac A and B patients and healthy men as control group. Hemophilia complication is chronic arthropathy that results from repeated joint bleeding, leading to limited movement. Limitation of jaw movement is present in patients with TMD. Hemophiliac patients were recruited in the Hemophilia outpatient clinic at Escola Paulista de Medicina, Universidade Federal de São Paulo (UNIFESP). The control group was composed of voluntary subjects recruited among medical and dental students of UNIFESP. Both groups were screened for TMD symptoms according to the European Academy of Craniomandibular Disorders questionnaire. The Research Diagnostic Criteria further evaluated those considered positive for TMD. The results showed a similar prevalence of TMD in the hemophiliac group compared to the control group $(n=38$, $n=79 ; p=0.7$ ). There were no significant differences in severity of sign and symptoms between the groups. In conclusion, patients with hemophilia do not have a higher prevalence of temporomandibular disorders, indicating absence of hemorrhage in temporomandibular joint.

KEY WORDS: temporomandibular joint, temporomandibular joint disorders, temporomandibular joint dysfunction syndrome, craniomandibular disorder, hemophilia A, hemophilia B.

\section{INTRODUCTION}

Temporomandibular disorder (TMD) encompasses a group of musculoskeletal and neuromuscular conditions that involve the masticatory musculature, temporomandibular joint (TMJ) and associated tissues (de Leeuw \& Klasser, 2013).

The TMD signs and symptoms are extremely common. Epidemiological studies suggest that $40 \%$ to $75 \%$ of the general population have some signs of TMD. The adult population of 20 to 40 years is the most affected. The female-to-male ratio of patients seeking care has been reported as ranging from 3:1 to 9:1 (Bagis et al., 2012; Huber \& Hall, 1990; Manfredini et al., 2006; Schiffman \& Fricton, 1988).
TMD pain could be associated with a dysfunction of the masticatory system, represented by clicking, locking of the TMJ and/or limitation of movement (de Leeuw \& Klasser).

Limitation of jaw movement can be a characteristic of patients with TMD. Pain associated with TMD can be clinically expressed as masticatory muscle pain (MMP) or TMJ pain produced by synovitis, capsulitis or osteoarthritis, sometimes resulting from previous hemarthrosis (de Leeuw \& Klasser).

A remarkable hemophilia complication is chronic arthropathy that results from repeated joint bleeding,

Department of Morphology and Genetics, Escola Paulista de Medicina, Universidade Federal de São Paulo and COLSAN, São Paulo, Brazil. * Department of Morphology and Genetics, Escola Paulista de Medicina, Universidade Federal de São Paulo, São Paulo, Brazil.

*** Dentistry, São Leopoldo Mandic, Campinas, São Paulo, Brazil

**** Hematology and Blood Transfusion Division, Hemophilia Service, Escola Paulista de Medicina, Universidade Federal de São Paulo, São Paulo, Brazil. 
leading to limited movement (Soucie et al., 2004). The most affected joints in descending order are the knee, elbow, ankle, foot, hip and shoulder (Greer \& Ballard, 1982), and hemarthrosis of the temporomandibular joint (TMJ) in patients with hemophilia is not frequently described.

There are few reports about TMD in patients with inherited bleeding disorders, two of them are case reports (Kaneda et al., 1979; Nishioka et al., 1988). High prevalence of TMD in hemophiliac patients $(77.7 \%)$ was pointed by authors from the Kirov Hematology Institute (Khokhrin et al., 2012).

Hemophilia is a rare, chronic, inherited bleeding disorder resulting from quantitative and/or qualitative deficiency of one or more plasma proteins (factors) of the clotting system. This disease is characterized by a deficiency in a specific clotting factor, resulting in the inability of the blood to clot normally and primarily affect males (Rogaev et al., 2009; Shastry et al., 2014).

Among inherited coagulopathies, the most common are hemophilia and von Willebrand disease (VWD). Hemophilia is a coagulation disorder resulting from X-linked genetic inheritance and is transmitted almost exclusively to males, carried by the apparently normal mother (most cases). Clinically it is characterized by bleeding, which may occur in any organ or structure of the affected patient. There are two types of hemophilias, A and B, caused by factor VIII and IX deficiency, respectively (Mannucci \& Tuddenham, 2001).

Hemophilia $B$ is indistinguishable in clinical aspects from hemophilia A. Its incidence is 3-4 times smaller than hemophilia A (Mannucci \& Tuddenham).

Since TMJ is submitted to high load during lifetime, the aim of this study was to investigate the prevalence of TMD in patients with severe and moderate type $A$ and $B$ hemophilia as compared to healthy control adults.

\section{MATERIAL AND METHOD}

This observational, cross-sectional study included 117 individuals. The study group consisted of 38 male hemophiliac patients (severe and moderate A and B) from the Hemophilia Outpatient Clinic of the Escola Paulista de Medicina, Universidade Federal de São
Paulo - UNIFESP (18-51 years old with a median age of 25 years), and the control group consisted of 79 healthy male voluntary subjects recruited among medical and dental students from UNIFESP (18-51 years old, median age 27 years old) (Table I). All participants gave written informed consent in accordance with the Helsinki Declaration. The study was approved by the Research Ethics Committee of UNIFESP (0107/10).

The type and severity of hemophilia were defined according to the plasma coagulant factor concentration (Mannucci \& Tuddenham).

Subjects were submitted to the European Academy of Craniomandibular Disorders questionnaire for assessing the presence of TMD symptoms. Those who answered YES to at least one question were submitted to axis I and II of the Research Diagnostic Criteria (RDC) (De Boever et al., 2008; Dworkin \& LeResche, 1992).

The RDC was also used to classify the TMD. In summary, the diagnostic system allows the possibility of multiple diagnoses for a given subject. Diagnoses were divided into three groups: a. muscle disorders, b. disc displacements and c.arthralgia, arthritis or arthrosis.

Controls met all five of the following criteria: 1) during the interview reported infrequent pain in the cheeks, jaw muscles, temples or jaw joints (no orofacial pain in the preceding month and no more than 4 days per month in any of the 5 months preceding that); 2) no more than 4 headaches per month within the preceding 3 months; 3 ) never diagnosed with TMD; 4) no use of night guard occlusal splint; and 5) during the examination, pain reported in the orofacial region for no more than 4 days in the prior 30 days.

Statistical analyses were performed using Person's Chi-square test, and differences were considered significant if $p<0.05$.

\section{RESULTS}

TMD diagnosis was performed according to the RDC (Dworkin \& LeResche). The frequency of TMD was $13.16 \%(5 / 38)$ in hemophiliac patients and $10.13 \%$ $(8 / 79)$ in the control group. There was no statistical difference between these groups $(p=0.70)$. 
Three patients were diagnosed with myofascial pain and two with myofascial pain and disc displacement with reduction. In the control group, five cases were diagnosed with myofascial pain, one with myofascial pain with limited opening and two with myofascial pain and disc displacement with reduction (Table II).
In the studied population, age did not influence the presence of TMD (Table II). Signs or symptoms of TMJ hemarthrosis were not observed in this study.

Table I. Diagnoses of temporomandibular disorders in case and control groups according to the Research Diagnostic Criteria (Dworkin \& LeResche, 1992).

\begin{tabular}{lccccc}
\hline & $\mathbf{n}$ & Median Age & Age Range & With TMD n (\%) & Without TMD n (\%) \\
\hline Cases & 38 & 25 & $18-51$ & $5(13.16 \%)$ & $33(86.84 \%)$ \\
Controls & 79 & 27 & $18-51$ & $8(10.13 \%)$ & $71(89.87 \%)$ \\
Total & 117 & & & $13(11.11 \%)$ & $104(88.88 \%)$ \\
\hline
\end{tabular}

$\mathrm{TMD}=$ Temporomandibular disorder; $\mathrm{P}$ value $=0.70$

Table II. Distribution of studied subjects according to age, hemophilia type and severity and presence or absence of temporomandibular disorder.

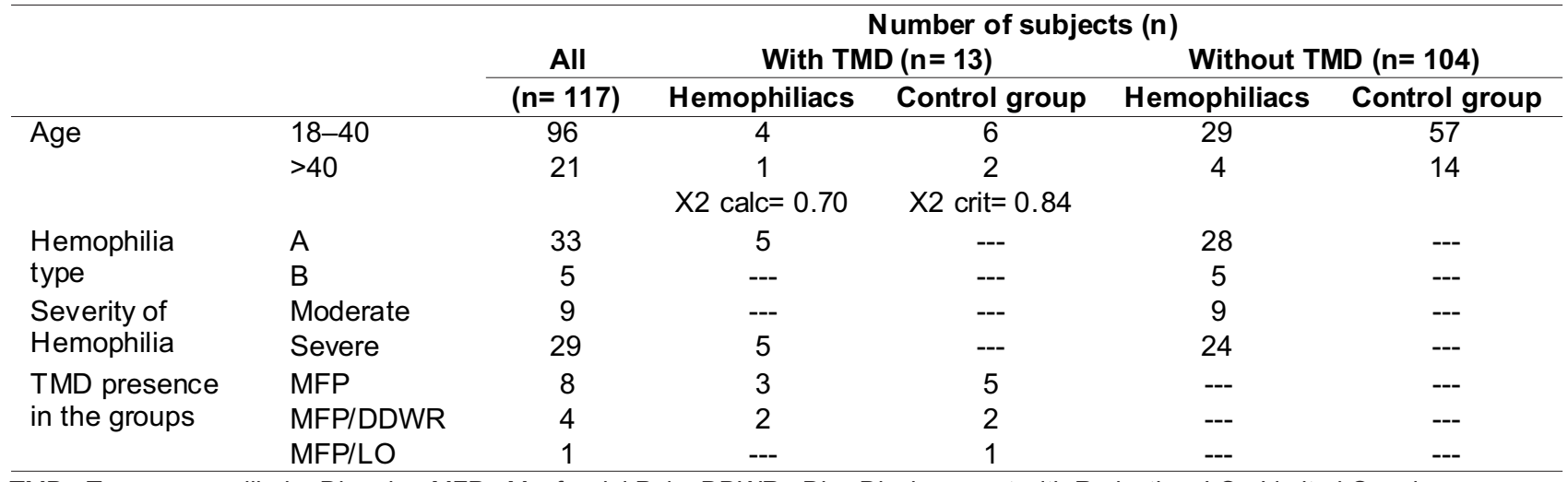

$\mathrm{TMD}=$ Temporomandibular Disorder; MFP= Myofascial Pain. DDWR= Disc Displacement with Reduction. LO= Limited Opening.

\section{DISCUSSION}

The TMJ is a synovial joint. It is a bilateral double joint but made of a single bone. This duplicity ensures movements that allow the complex act of chewing, requiring integrity of both sides, but at the same time causes a restrictive action on the jaw movements (Alomar et al., 2007; Iwasaki et al., 2004). The most affected joints in hemophiliac patients in descending order are the knee, elbow, ankle, foot, hip and shoulder (Greer \& Ballard).

We observed a low frequency of TMD in hemophiliac individuals as compared to Russian study (Khokhrin et al.). This study addressed articular dysfunction of the TMJ in $77.7 \%$ of 45 hemophiliac male patients aged from 12 to 57 years old from the Kirov Hematology Institute. However, this publication did not analyze a control group, which renders their findings questionable. Furthermore, they did not use RDC as diagnosis criteria for TMD. They used a symptom severity index based on personal criteria, with no mention about its validation in literature.

Furthermore, the literature presented two case reports addressing this issue, a case of TMJ acute hemarthrosis associated with factor IX deficiency in a 3 years old boy (Kaneda et al.) and a case of an 18 year-old white woman diagnosed as factor $\mathrm{XI}$ deficiency and TMJ bilateral internal derangement with myofascial pain-dysfunction (Nishioka et al.).

Hemarthrosis of the temporomandibular joint (TMJ) in patients with hemophilia is not usually reported. 
In the sample of 38 hemophiliac male patients here studied, there was a low prevalence and no difference when compared with a control group assessed about TMD symptoms.

A possible explanation for our findings may be the fact that this joint is highly specialized, and it is unique in both morphological and functional aspects when compared to the other joints of the human body. The venous pattern is diffuse, forming a plentiful plexus all around the capsule. Posteriorly, the retrodiskal pad is copiously riddled with wide venous channels. These cavernous spaces fill and empty as the condyle rocks rhythmically forward and backward, providing for unhampered, nimble movement in normal joint action. A similar venous nimble movement in normal joint action feature is also seen anteriorly but to a lesser degree (Alomar et al.).

The relationship among neuromuscular control of TMJ loads, direction of joint loads as dictated by dental eruption and growth of the TMJ eminence (Bag et al., 2014) suggest that the latter is consistent with a neuromuscular objective of joint load minimization. This hypothesis has been tested in a numerical model based on joint load minimization to predict effective sagittal TMJ eminence shapes in healthy humans (Iwasaki et al., 2003a, 2003b, 2004, 2010; Nickel et al., 2002, 2003).

Hemophilia is a disorder that affects almost exclusively men (Loomans et al., 2014). On the other hand, epidemiological studies have documented a greater frequency of TMD in females (Bagis et al.; Huber \& Hall; Manfredini et al.; Schiffman \& Fricton). This condition could also have some contribution to our results.
In this study, only moderate and severe cases were included because these subgroups present higher bleeding tendency. There is the possibility that these patients may have had hemarthrosis without symptoms and signs of TMD.

Another hypothesis for our findings is because hemophiliacs face many painful bleeding episodes and could develop mechanisms to support a higher level of pain during life. This situation could increase their pain threshold, as happens with athletes who have periods of intense pain during training (Tesarz et al., 2012). Therefore, as athletes, the hemophiliac patients could develop the ability to tolerate pain. If this conjecture is true, the pressure used during the palpation exam (RDC axis I) was not sufficient to detect a TMD, and that could explain at least part of this study's findings.

This palpation's pressure is preset in the RDC, but to patients with special conditions there is no further information. A hidden TMD could be, in the future, worse to the hemophiliac patients' quality of life.

Even though hemophiliac patients could have several joints affected as a consequence of bleeding episodes, we did not find TMD in our cohort. However, our study highlighted the necessity of improving our knowledge on TMD in this population. Further studies are needed to clarify this issue.

\section{ACKNOWLEDGMENTS}

This research was sponsored by COLSAN Associação Beneficiente de Coleta de Sangue.

GUIMARÃES, T. B.; FERREIRA-CABRINI, M. B.; QUAGLIO, C. L.; GUIMARÃES, A. S.; SMITH, R. L.; ANTUNES, S. V. \& ALONSO, L. G. Trastorno temporomandibular: Prevalencia en pacientes hemofílicos. Int. J. Odontostomat., 9(2):295-300, 2015.

RESUMEN: El objetivo fue investigar la prevalencia de trastornos temporomandibulares (TTM) entre pacientes hemofílicos A y B severos y moderados, y hombres sanos como grupo de control. Una complicación de la Hemofilia es la artropatía crónica como resultado de una hemorragia articular a repetición, limitando el movimiento en el tiempo. La limitación del movimiento de la mandíbula está presente en pacientes con TTM. Los pacientes hemofílicos fueron reclutados en la clínica de atención ambulatoria de hemofilia en Escola Paulista de Medicina, Universidade Federal de São Paulo (UNIFESP). El grupo control estaba compuesto por sujetos voluntarios reclutados entre los estudiantes de Medicina y Odontología de UNIFESP. Ambos grupos fueron evaluados por síntomas de TTM según cuestionario de trastornos craneomandibulares de la Academia Europea. Los criterios de diagnósticos de investigación evaluados se consideraron positivos para TTM. Los resultados mostraron una prevalencia similar de TTM en el grupo de hemofílicos en comparación con el grupo control $(n=38, n=79 ; p=0,7)$. No se encontraron diferencias significativas en la gravedad de los signos y síntomas entre los grupos. En conclusión, los pacientes con hemofilia no tienen una mayor prevalencia de trastornos temporomandibulares, indicando la ausencia de hemorragia en la articulación temporomandibular.

PALABRAS CLAVE: articulación temporomandibular, trastornos de la articulación temporomandibular, síndrome de disfunción de la articulación temporomandibular, trastornos craneomandibulares, hemofilia A, hemofilia B. 
GUIMARÃES, T. B.; FERREIRA-CABRINI, M. B.; QUAGLIO, C. L.; GUIMARÃES, A. S.; SMITH, R. L.; ANTUNES, S. V. \& ALONSO, L. G. Temporomandibular disorder: prevalence among hemophiliac patients. Int. J. Odontostomat., 9(2):295-300, 2015.

\section{REFERENCES}

Alomar, X.; Medrano, J.; Cabratosa, J.; Clavero, J. A.; Lorente, M.; Serra, I.; Monill, J. M. \& Salvador, A. Anatomy of the temporomandibular joint. Semin. Ultrasound CT. MR., 28(3):170-83, 2007.

Bag, A. K.; Gaddikeri, S.; Singhal, A.; Hardin, S.; Tran, B. D.; Medina, J. A. \& Curé, J. K. Imaging of the temporomandibular joint: An update. World J. Radiol., 6(8):567-82, 2014.

Bagis, B.; Ayaz, E. A.; Turgut, S.; Durkan, R. \& Özcan, M. Gender difference in prevalence of signs and symptoms of temporomandibular joint disorders: a retrospective study on 243 consecutive patients. Int. J. Med. Sci., 9(7):539-44, 2012.

De Boever, J. A.; Nilner, M.; Orthlieb, J. D.; Steenks, M. H. \& Educational Committee of the European Academy of Craniomandibular Disorders. Recommendations by the EACD for examination, diagnosis, and management of patients with temporomandibular disorders and orofacial pain by the general dental practitioner. J. Orofac. Pain, 22(3):268-78, 2008.

de Leeuw, R. \& Klasser, G. D. (Eds.). Orofacial Pain: Guidelines for Assessment, Diagnosis, and Management. 5th Ed. Chicago, Quintessence, 2013.

Dworkin, S. F. \& LeResche, L. Research diagnostic criteria for temporomandibular disorders: review, criteria, examinations and specifications, critique. $J$. Craniomandib. Disord., 6(4):301-55, 1992.

Greer, R. B. 3rd. \& Ballard, J. O, 3rd. Musculoskeletal bleeding in hemophilia. Pediatr. Ann., 11(6):521-4, 5267, 1982 .

Huber, M. A. \& Hall, E. H. A comparison of the signs of temporomandibular joint dysfunction and occlusal discrepancies in a symptom-free population of men and women. Oral Surg. Oral Med. Oral Pathol. Oral Surg. Oral Med. Oral Pathol., 70(2):180-3, 1990.

Iwasaki, L. R.; Baird, B. W.; McCall, W. D. Jr. \& Nickel, J. C. Muscle and temporomandibular joint forces associated with chincup loading predicted by numerical modeling. Am. J. Orthod. Dentofacial Orthop., 124(5):530-40, 2003a.

Iwasaki, L. R.; Crosby, M. J.; Marx, D. B.; Gonzalez, Y.; McCall, W. D. Jr.; Ohrbach, R. \& Nickel, J. C. Human temporomandibular joint eminence shape and load minimization. J. Dent. Res., 89(7):722-7, 2010.

Iwasaki, L. R., Petsche, P. E., McCall, W. D., Jr., Marx, D. \&
Nickel, J. C. Neuromuscular objectives of the human masticatory apparatus during static biting. Arch. Oral Biol., 48(11):767-77, 2003b.

Iwasaki, L. R.; Thornton, B. R.; McCall, W. D. Jr. \& Nickel, J. C. Individual variations in numerically modeled human muscle and temporomandibular joint forces during static biting. J. Orofac. Pain, 18(3):235-45, 2004.

Kaneda, T.; Nagayama, M.; Ohmori, M.; Minato, F.; Nakajima, J. \& Shikimori, M. Hemarthrosis of the temporomandibular joint in a patient with hemophilia B: report of case. J. Oral Surg., 37(7):513-4, 1979.

Khokhrin, D. V.; Gileva, O. S.; Khaliavina, I. N. \& Nazukin, E. D. TMJ pathology in hemophilia patients. Stomatologiia (Mosk.), 91(2):46-8, 2012.

Loomans, J. I.; Lock, J.; Peters, M.; Leebeek, F. W.; Cnossen, M. H. \& Fijnvandraat, K. Haemophilia. Ned. Tijdschr. Geneeskd., 158:A7357, 2014.

Manfredini, D.; Chiappe, G. \& Bosco, M. Research diagnostic criteria for temporomandibular disorders (RDC/TMD) axis I diagnoses in an Italian patient population. J. Oral Rehabil., 33(8):551-8, 2006.

Mannucci, P. M. \& Tuddenham, E. G. The hemophilias--from royal genes to gene therapy. N. Engl. J. Med., 344(23):1773-9, 2001.

Nickel, J. C.; Iwasaki, L. R.; Walker, R. D., McLachlan, K. R. \& McCall, W. D. Jr. Human masticatory muscle forces during static biting. J. Dent. Res., 82(3):212-7, 2003.

Nickel, J. C.; Yao, P.; Spalding, P. M. \& Iwasaki, L. R. Validated numerical modeling of the effects of combined orthodontic and orthognathic surgical treatment on TMJ loads and muscle forces. Am. J. Orthod. Dentofacial Orthop., 121(1):73-83, 2002.

Nishioka, G. J.; Van Sickels, J. E. \& Tilson, H. B. Hemophilic arthropathy of the temporomandibular joint: review of the literature, a case report, and discussion. Oral Surg. Oral Med. Oral Pathol., 65(2):145-50, 1988.

Rogaev, E. I.; Grigorenko, A. P.; Faskhutdinova, G.; Kittler, E. L. \& Moliaka, Y. K. Genotype analysis identifies the cause of the "royal disease". Science, 326(5954):817, 2009.

Schiffman, E. \& Fricton, J. R. Epidemiology of TMJ and craniofacial pains: an unrecognized societal problem. In: Fricton, J. R.; Kroening, R. J. \& Hathaway, K. M., (Eds.). TMJ and craniofacial pain: diagnosis and management. St. Louis \& Tokyo, Ishiyaku EuroAmerica, 1988. 
GUIMARÃES, T. B.; FERREIRA-CABRINI, M. B.; QUAGLIO, C. L.; GUIMARÃES, A. S.; SMITH, R. L.; ANTUNES, S. V. \& ALONSO, L. G. Temporomandibular disorder: prevalence among hemophiliac patients. Int. J. Odontostomat., 9(2):295-300, 2015.

Shastry, S. P.; Kaul, R.; Baroudi, K. \& Umar, D. Hemophilia A: Dental considerations and management. J. Int. Soc. Prev. Community Dent., 4(Suppl. 3):S147-52, 2014.

Soucie, J. M.; Cianfrini, C.; Janco, R. L.; Kulkarni, R.; Hambleton, J.; Evatt, B.; Forsyth, A.; Geraghty, S.; Hoots, K.; Abshire, T.; Curtis, R.; Forsberg, A.; Huszti, H.; Wagner, M. \& White, G. C. 2nd. Joint range-of-motion limitations among young males with hemophilia: prevalence and risk factors. Blood, 103(7):2467-73, 2004.

Tesarz, J.; Schuster, A. K.; Hartmann, M.; Gerhardt, A. \& Eich, W. Pain perception in athletes compared to normally active controls: a systematic review with meta-analysis. Pain, 153(6):1253-62, 2012.
Correspondence to:

Thatiana Bastos Guimarães

TMD and OFP Outpatient Clinic

Escola Paulista de Medicina

Universidade Federal de São Paulo

Rua Botucatu, 740

São Paulo

BRAZIL

Email: thatianaguimaraes@uol.com.br

Received: 09-06-2014

Accepted: 14-07-2015 